\title{
UNIÃO ESTÁVEL OU CASAMENTO FORÇADO?
}

\author{
Mário Luiz Delgado* \\ Débora Vanessa Caús Brandão**
}

Sumário: Introdução - 1. Casamento e união estável: distinções necessárias 2. Evolução legislativa da união estável no Brasil - 3. O tratamento legislativo da união estável em outros países. - 4. Crítica à disciplina legislativa da união estável no Brasil - 5. Situações de perplexidade causadas por interpretações divergentes do texto constitucional - 6. A equiparação de efeitos jurídicos transforma a União Estável em um verdadeiro casamento forçado - Conclusões - Referências.

"e mariage forcé concerne des enfants, des femmes, des hommes promis ou donnés en mariage contre leur gré, à une personne connue ou inconnue, sans qu'ils aient eu le droit de refuser. Il est considéré comme une

* Doutor em Direito Civil pela USP e Mestre em Direito Civil Comparado pela PUC-SP. Especialista em Direito Processual Civil pela Universidade Federal de Pernambuco. Professor Titular da Faculdade Autônoma de Direito de São Paulo - FADISP e Professor de Direito Civil na Escola Paulista de Direito - EPD. Diretor do Instituto dos Advogados de São Paulo- IASP e Presidente da Comissão de Assuntos Legislativos do Instituto Brasileiro de Direito de Família - IBDFAM. É membro da Academia Brasileira de Direito Civil- ABDC e do Instituto de Direito Comparado Luso Brasileiro - IDCLB.

** Doutora e Mestre em Direito das Relaçôes Sociais pela PUC/SP. Pós Doutora em Direitos Humanos pela Universidade de Salamanca, Espanha. Professora Titular de Direito Civil da Faculdade de Direito de São Bernardo do Campo/SP, Universidade Municipal de São Caetano do Sul e professora convidada dos cursos de Pós-graduação da Escola Paulista de Direito EPD. É membro da International Society of Family Law - ISFL, do Instituto Brasileiro de Direito de Família - IBDFAM e Instituto de Direito Privado - IDP. Advogada. 
.. Direito Civil: Estudos | Coletânea do XV Encontro dos Grupos de Pesquisa - IBDCivil

atteinte à la liberté individuelle. Il renvoie à l'idée
que l'un des deux partenaires ou les deux n'ont pu
consentir à leur mariage. Il est considéré comme un
acte contraire aux droits fondamentaux de la person-
ne et reconnu como une violence" (RUDE-ANTOI-
NE, Edwige. Mariage libre mariage forcé? Paris:
Presses Universitaires de France - PUF, 2011, p. 5).

\section{INTRODUÇÃO}

A citação que emoldura este artigo traduz o cerne das nossas reflexões: até que ponto a atribuição de direitos e deveres às uniōes de fato, cuja constituição teria sido supostamente presidida pelo desejo de não submissão às formalidades sacramentais do casamento, não estaria descaracterizando-as no seu prisma fundamental de uniāo livre ou união informal, para transformá-las, na prática, em um tertium genus de casamento. Um casamento com menos formalidades, mas com os mesmos direitos e os mesmos deveres recíprocos. Um casamento imposto pelo Estado contra a vontade dos nubentes.

O Código Civil brasileiro de 2002 disciplinou os direitos e deveres dos que convivem em união estável, assegurando aos companheiros um estatuto legal em muitos aspectos semelhante, mas jamais idêntico, ao dos cônjuges. A união estável, aos olhos do legislador de 2002, é uma situação de fato, consagrada pela realidade social, em tudo semelhante ao casamento, mas que não obedeceu a determinadas formalidades exigidas em lei. Por isso, a mens legislatoris na ocasião foi guindar a união estável quase ao patamar do casamento civil, com largueza de espírito, mas sem incorrer no equívoco da equiparação plena, sob pena de diluir por completo as diferenças existentes entre as duas entidades familiares, posição esta que há muito sustentamos inquinada de inconstitucional populismo doutrinário.

Da experiência verificada no direito comparado não localizamos exemplos abundantes de equiparação entre casamento e estável. Antes pelo contrário, a posição predominante talvez ainda possa ser traduzida pela máxima de Napoleão: "le concubins se passent de la loi, la loi se desinteresse d'eux". Em grande parte dos países, o casamento é a instituição regra e ainda que se reconheçam efeitos jurídicos às uniōes de fato, mesmo porque viver informalmente é bem diferente do que viver fora das leis ${ }^{1}$, não se cogita equiparar as duas figuras jurídicas.

1 PITÃO, José Antônio de França. Uniōes de facto e economia comum. 3. ed. Coimbra: Almedina, 2011, p. 46. 
Entretanto, o Brasil caminha na direção oposta, a ponto de a posição a favor do tratamento diferenciado entre união estável e casamento estar sendo contestada, tanto na doutrina, como na jurisprudência. Alguns tribunais, por exemplo, chegam a afastam a aplicação do art. 1.790 do CCB/2002, que regula a sucessão entre os companheiros, por reputá-lo inconstitucional, uma vez a Constituição, segundo essa corrente, não permitiria a diferenciação entre famílias assentadas no casamento e na união estável.

Com o devido respeito aos partidários do pleno igualitarismo entre união estável e casamento, consideramos equivocada tal posição.

A orientação jurisprudencial e doutrinária pelo igualitarismo das entidades familiares está se sobrepondo à própria liberdade daqueles que optaram pela relação informal, exatamente por não desejarem se submeter ao regime formal do casamento, o que resulta, em última análise, tornar ineficaz a parte final do $₫ 3^{\circ}$ do artigo $226 \mathrm{da} \mathrm{CF} / 88$, que impôs ao legislador infraconstitucional facilitar a conversão da união estável em casamento.

Não compete ao legislador, nem muito menos à jurisprudência, regulamentar a união estável a ponto de atribuir-lhe direta e autoritariamente os efeitos da sociedade conjugal, o que implica, na prática, transformar a união estável em casamento contra a vontade dos conviventes, aos quais estar-se-ia impondo um verdadeiro "casamento forçado".

\section{CASAMENTO E UNIÃO ESTÁVEL: DISTINÇÕES NECESSÁRIAS}

Sabemos encontrar-se há muito superada a concepção monopolista do casamento como formatação legal da família, desde que se conseguiu distinguir o direito de constituir família e o direito de contrair casamento. O elenco das entidades familiares posto no art. 226 do pergaminho constitucional é reconhecido, de forma quase consensual, como meramente exemplificativo. Consoante entendimento de Mário Delgado, rol aberto a comportar indefinidas formas de constituição de família, todas elas igualmente protegidas pelo Estado. O ponto em comum a todas, a justificar o reconhecimento e o incentivo estatal é a afetividade, pois se muitas são as famílias em seus diversos arranjos familiares próprios, inegável que todas elas terão a sua formação pressuposta pelo afeto, como elo que as une e reúne. Já para Débora Brandão, o legislador reconhece tão somente o que consta no texto constitucional, devendo qualquer outra forma ser objeto de emenda constitucional.

O conceito legal de família que melhor traduz essa diversidade nos foi legado pela Lei n. 11.340/2006 (Lei Maria da Penha), que define a família como sendo a 
comunidade formada, em face da parentalidade legal ou admitida, por afinidade, ou por vontade expressa (art. 50, II).

A tutela estatal abrangente das entidades familiares típicas e atípicas não implica equiparação da respectiva moldura normativa, posto que em sendo diversas as suas características, imperioso reconhecer a diversidade de regimes legais, sem que se incorra no equívoco da hierarquização. Não existem famílias mais ou menos importantes, mais ou menos reconhecidas, mas, simplesmente, famílias diferentes, cada qual a seu modo, e, por isso mesmo, mais ou menos reguladas.

Casamento e união estável são duas entidades familiares típicas, mas com enorme diferenciação fática e normativa.

O ponto distintivo fundamental reside no seu modo de constituição e desconstituição.

Pela redação original do texto constitucional, considera-se união estável a união entre homem e mulher e, acrescenta o comando para que a lei facilite sua conversão em casamento. Ora, não há como se recomendar a conversão de algo naquilo que ele já o é. Portanto, é notória a inconstitucionalidade da tese sustentada acerca da equiparação dos institutos do casamento e da união estável. Não se obriga qualquer pessoa a se casar, mas quem escolhe a união estável deveria estar ciente de que não se poderia receber a mesma tutela jurídica.

O casamento pressupõe um ato formal e solene, diante do representante do Estado, precedido pelo procedimento de habilitação perante o Cartório de Registro Civil das Pessoas Naturais, destinado a apurar a capacidade matrimonial dos nubentes, ou seja, para verificar se eles preenchem os requisitos legais para a formalização do ato. Em regra, a prova da existência do casamento se dá com a certidão do registro, à exceção do casamento nuncupativo, consoante o artigo 1540 do Código Civil. A prova de sua existência é exclusivamente documental, através de certidão extraída do assento público competente. A dissolução também exige um procedimento próprio e deliberação estatal, seja por ação judicial, seja por ato notarial.

A prova de que o matrimônio se dissolveu também se faz por certidão, pouco importando a realidade dos fatos. Se os ex-cônjuges, depois de divorciados, retomam a convivência como se ainda casados fossem, tal fato jamais terá o condão de restaurar o casamento.

A união estável, por sua vez, não exige formalidade, nem solenidade, mas pressupóe o fato da convivência pública, duradoura e com o objetivo de constituição de família. Ela se manifesta pela simples comunhão fática de vida, ou seja, o casal passa a conviver pautado sob estes elementos acima descritos, independente- 
mente de vida sob o mesmo teto, contrato escrito ou qualquer outra providência. A prova de sua existência é preponderantemente testemunhal, não obstante seja comumente corroborada por documentos (como fotos, contrato de alugueis, bilhetes amorosos etc.), dentre os quais, e certamente o mais relevante, o contrato de convivência. De acordo com a Escada Ponteana, o instrumento contratual foi redigido, portanto, existe; é válido, se observados todos os requisitos legais (apesar das críticas aqui expostas), mas não gozará de eficácia enquanto não for constituída a união pelo convívio público, contínuo, duradouro e com o objetivo de se constituir família.

Ou seja, jamais o instrumento contratual poderá constituir a união estável, especialmente quando celebrado no início da convivência. $O$ contrato prévio de união estável não tem eficácia enquanto as partes contratantes não concretizarem o efetivo convívio. No máximo exterioriza tratativas preliminares de um convívio futuro, que poderá se materializar ou não, assemelhando-se, nesse ponto, ao pacto antenupcial, que somente adquire eficácia após o casamento. Sua eficácia é condicionada, dependendo do implemento ulterior dos seus elementos caracterizadores.

Uma união de fato, iniciada com ou sem contrato, tem o seu potencial de transformar-se ou não em uma união estável, a depender da presença dos demais elementos característicos. Assim, um relacionamento pode avançar e se caracterizar como união estável ou não, ficando no plano do namoro ou em encontros eventuais. Isto vai depender da presença dos demais elementos caracterizadores da união estável, donde se conclui que a verificação da existência da união estável só pode se dar com ela em curso. Essa aferição se fará sempre a posteriori, ao contrário do casamento, sempre a priori.

A dissolução da união estável, tanto quanto a sua constituição, portanto, decorre de um fato da vida, o fato da cessação da convivência, não exigindo qualquer procedimento ou formalidade. Da mesma forma que a união estável não se inicia por se firmar um contrato de convivência ou uma escritura pública de união estável, ela não se extingue por conta da lavratura de um distrato, de uma escritura pública de dissolução de união estável, ou da propositura de ação judicial de extinção de união estável, uma vez que tudo deve se dar no plano dos fatos.

A separação de fato com animus de definitividade é quanto basta para dissolver a união, sem necessidade de interveniência do Estado. A prova da dissolução é também predominantemente testemunhal, podendo ser corroborada por outros elementos, como comprovante de residência em localidade diversa ou mesmo uma simples declaração de um dos conviventes de que cessou a convivência more uxorio. 
Todavia, nem mesmo o distrato formalizado de um contrato de união estável produzirá qualquer efeito desconstituidor se os distratantes continuarem a conviver de forma pública, contínua e duradoura, com o objetivo de constituição de família.

Em suma, da mesma forma que a união estável não se inicia por se firmar um contrato de convivência ou uma escritura pública de união estável, ela não se extingue por conta da lavratura de um distrato, de uma escritura pública de dissolução de união estável, ou da propositura de ação judicial de extinção de união estável, uma vez que tudo deve se dar no plano dos fatos.

Os companheiros poderão realizar o procedimento estabelecido no Código de Processo Civil, art. $732^{2}$, caso queiram, mas não há qualquer obrigatoriedade porque a união estável se extingue com o fato da vida. Aqui, porém, e mais uma vez, o legislador brasileiro insiste na aproximação com o instituto do casamento: para tal, basta a constatação do texto legal.

$\mathrm{Se}$, a despeito da existência destes documentos, o casal continua convivendo de acordo com o preceituado no art. 1723 do $\mathrm{CC}^{3}$, não há qualquer hipótese de se admitir a cessação da união estável.

Assim, nos elementos gênese, êxodo e prova reside a grande distinção, a justificar, também por isso, a desigualdade de regramentos legais.

\section{EVOLUÇÃO LEGISLATIVA DA UNIÃO ESTÁVEL NO BRASIL}

O Código Civil albergou a união estável em posição de destaque, ao ensejo de regulamentar o art. 226, $\$ 3^{\circ}$ da Carta Magna, além de substituir a regulação anterior trazida pelas leis n. 8.971, de 29 de dezembro de 1994 e 9.278, de 10 de maio de 1996.

Constituição e Código Civil atual repetem que a união estável é caracterizada pela convivência pública, contínua e duradoura, estabelecida com o objetivo de constituir família.

No Código Civil de 1916, não se reconheciam direitos às famílias de fato, ou "não casamentárias", constituídas fora do casamento civil ou religioso com efeitos civis. As poucas referências do texto codificado anterior tinham sempre o cunho

2 Art. 732. As disposições relativas ao processo de homologação judicial de divórcio ou de separação consensuais aplicam-se, no que couber, ao processo de homologação da extinçãa consensual de união estável.

3 Art. 1.723. É reconhecida como entidade familiar a união estável entre o homem e a mulher, configurada na convivência pública, contínua e duradoura e estabelecida com o objetivo de constituição de família. 
repressor, procurando deixar o então chamado concubinato à margem de qualquer proteção jurídica. Não havia distinção, na esfera legislativa, entre o concubinato ostensivo e o clandestino, nem tão pouco entre o concubinato puro e o impuro.

Aos poucos a legislação foi assegurando certos direitos às uniōes fáticas, seguindo as orientações que já estavam sendo firmadas pelos tribunais. Diversas leis ordinárias passaram a conferir direitos às companheiras, sobretudo direitos previdenciários.

A Lei n. 6.015, de 31 de dezembro de 1973, por exemplo, anterior à atual Constituição, assegurou o direito da mulher ao nome do companheiro (art. 57, $\$ \$ 2^{\circ}$ a $6^{\circ}$ ). A Lei n. 6.858 , de 24 de novembro de 1980 tratou da dependência do companheiro para levantamento de certos valores do autor da herança (art. 1.037 do CPC).

Com o advento da Constituição Federal de 1988, a união estável foi alçada à categoria de entidade familiar. Ressalte-se que o legislador constituinte substituiu intencionalmente a palavra concubinato pela expressão união estável, tentando espancar toda a carga de preconceitos que jazia sobre a velha expressão, numa prova de aceitação, compreensão e respeito aos direitos daqueles que viviam em uniões informais.

Em face do mandamento constitucional de proteção à união estável como entidade familiar (art. 226, $\$ 3^{\circ}$ ), foram editadas, em curto espaço de tempo, diversas leis extravagantes, que asseguraram, dentre outros direitos: adoção de filho por "concubinos" (Lei n. 8.069/90, art. 42, $\$ 2^{\circ}$ ); dependência do companheiro para fins previdenciários (Lei n. 8.213, de 24 de julho de 1991); impenhorabilidade do bem de família(Lei n. 8.009, de 29 de março de 1990); sub-rogação do companheiro na locação de imóveis urbanos, em caso de dissolução da vida em comum com o locatário ou de seu falecimento (Lei n. 8.245, de 18 de outubro de 1991, arts. 11 e 12).

E finalmente as duas leis especiais que regulamentaram a união estável na seara infraconstitucional até o advento do CC/2002: Lei n. 8.971/1994, dispondo sobre os direitos de companheiros a alimentos, sucessão (herança e usufruto) e meação em caso de morte e Lei n. 9.278/96, que deu nova definição à união estável, estabelecendo os direitos e deveres dos conviventes, tratando da assistência material (alimentos) em caso de rescisão da união estável, garantindo o condomínio (meação) dos bens adquiridos na constância da união e a título oneroso (salvo estipulação contratual em contrário), acrescentando o direito de habitação no plano da sucessão hereditária, permitindo a conversão da união estável em casamento por requerimento ao Oficial do Registro Civil. 
O Código Civil de 2002, por sua vez, reconhece a união estável como entidade familiar, reproduzindo o art. $1^{\circ}$ da Lei n. 9.278/96, sem mencionar prazo mínimo para a sua caracterização, exigindo apenas que a união seja pública, contínua e duradoura, com o objetivo de constituição de família. Também dispôs, seguindo o estabelecido no art. $226, \$ 3^{\circ} \mathrm{da} \mathrm{CF} / 88$, que a união estável poderá ser convertida em casamento, mediante pedido dos companheiros ao juiz competente e assento no Registro Civil.

Além dos dispositivos constantes do título específico "Da União Estável" (Arts. 1.723/1.727), o CC/2002 também tratou da matéria em vários artigos, tais como:

- Art. 793: institui o companheiro como beneficiário de seguro, se ao tempo do contrato o segurado estivesse separado de fato ou judicialmente.

- Art. 1.562: possibilita a propositura da medida judicial de separação de corpos por um dos conviventes.

- Art. 1.595: institui o parentesco por afinidade na união estável.

- Art. 1.694: estabelece o dever de alimentos entre companheiros.

- Art. 1.711: possibilita a instituição de bem de família, mediante escritura pública, testamento ou doação pelos cônjuges ou conviventes.

- Art. 1.775: prevê a curatela do cônjuge ou do companheiro

- Art. 1.790: estabelece os direitos sucessórios do companheiro sobrevivente.

- Art. 1.797: equipara o companheiro ao cônjuge na preferência pela administração da herança.

\section{O TRATAMENTO LEGISLATIVO DA UNIÃO ESTÁVEL EM OUTROS PAÍSES.}

$\mathrm{Na}$ maioria dos países inexiste estatuto específico para as uniões fáticas, que discipline, de forma sistematizada, as suas relações patrimoniais. E muito menos que as equipare totalmente ao casamento.

No direito francês, por exemplo, vislumbram-se duas formas de uniões livres, o concubinato (concubinage) e o pacto civil de solidariedade (PACS), sendo que nenhuma das duas se equipara ao casamento (mariage).

Os conviventes ou pacsés se diferenciam dos concubinos, pois os primeiros possuem o registro documental da convivência fornecido pelo Estado através de um certificado. Os casais franceses, que possuem união de fato e que queiram assegurar alguns direitos (seguro social, benefícios alimentares, pensões, etc.) se dirigem à Prefeitura (Mairie) do local de sua residência, apresentando testemunhas e 
prova de domicílio ou residência, e pedem certificados de que são companheiros. A partir daí deixam de ser concubinos e se tornam pacsés. No direito sucessório gaulês, os componentes quer do PACS, quer do concubinato, não herdam um do outro.

$\mathrm{Na}$ Alemanha a regra continua sendo o casamento civil, muito embora a lei busque facilitar os trâmites administrativos e baratear os custos das uniôes matrimoniais.

$\mathrm{Na}$ Espanha existe o casamento civil e o casamento religioso, ambos reconhecidos pelo Estado. As referências à união de fato são esparsas. Não são aplicáveis direitos e deveres dos cônjuges, não há obrigação alimentar, deveres de assistência e fidelidade, direitos sucessórios. Os efeitos são exclusivamente patrimoniais e pressupóem dois requisitos essenciais: a exigência de um certo tempo de convivência para derivar determinados feitos jurídicos, e a existência de um contrato formal de convivência, que represente a base geradora dos mencionados efeitos de direito. Registra LUIZ PAULO CONTRIM que "a jurisprudência do Supremo Tribunal espanhol, hodiernamente, vem decidindo que a existência de uma sociedade universal entre os conviventes (CC, art. 1.674) - sociedade universal de ganâncias - depende, de um lado, do nítido consentimento entre eles, traduzido pela affectio societatis, e de outro, da prova do acordo de que as aquisições patrimoniais foram realizadas por ambos os conviventes" ${ }^{\text {. }}$.

No direito norte-americano existe o casamento e o chamado common law marriage ou casamento de fato, mas a tendência legislativa é orientada à tutela do matrimônio institucional. Inclusive na grande maioria dos estados americanos, apegados ao conceito de casamento tradicional, sequer é reconhecido o common law marriage e simplesmente se negam quaisquer direitos aos conviventes ${ }^{5}$. Existem também os contratos de vida em comum ("living together contracts"), celebrados por "pares solteiros" para assegurar certos direitos em caso de rompimento futuro.

O Código Civil Mexicano inclui a companheira na ordem da vocação hereditária, se conviveu por cinco anos ininterruptos com o autor da herança ou que teve filhos. Se o de cujus deixar várias concubinas nenhuma delas terá direito sucessório (art. 1.645, caput), preservando-se a moralidade e o dever de fidelidade da união concubinária. Devendo o testador prestar alimentos à companheira, se com ela conviveu mais de cinco anos, ou se da união resultou prole (art. 1.368, V).

4 Ob. cit.

5 AZEVEDO, Álvaro Villaça. Estatuto da família de fato: de acordo com o novo Código Civil. 2. ed. São Paulo: Atlas, 2002, p. 99. 
Em outros países, é a lei que determinará os casos em que, por razão de equidade, a união entre pessoas com capacidade legal para contrair matrimônio, deva ser equiparada, por sua estabilidade e singularidade ao matrimônio civil.

\section{CRÍTICA À DISCIPLINA LEGISLATIVA DA UNIÃO ESTÁVEL NO BRASIL}

Desde o advento das primeiras leis promulgadas após a $\mathrm{CF} / 88$, que pretenderam regulamentar a união estável no Brasil, alguns autores já criticavam o conteúdo dessa regulamentação.

$\mathrm{Na}$ opinião de Maria Helena Diniz, por exemplo, as Leis n. 8.971/94 e 9.278/96 e o novo Código Civil, em algumas normas referentes ao Direito de Família eram "inconstitucionais por estimularem o concubinato puro em alguns de seus artigos, mas é inegável que os direitos e deveres outorgados aos conviventes por essas normas encontram respaldo na jurisprudência e na doutrina, fazendo com que tenham eficácia social. Resta-nos aceitar os seus efeitos jurídicos, ante a teoria da incidência normativa, que privilegia o fenômeno eficacial e não o da validade. $\mathrm{O}$ rigor científico requer que se estabeleça um entrelaçamento entre tais normas, para que haja unidade de coerência lógica do sistema normativo. Como há divórcio entre o art. 226, $\$ 3^{\circ}$, da CF/88, o Código Civil e as Leis ns. 8.971 e 9.278, será preciso por um fim ao conflito, sem contudo, eliminá-lo." ${ }^{\prime}$

Com efeito, o texto constitucional, ao reconhecer a união estável como entidade familiar deixou claro que o fez apenas para fins de proteção do Estado (artigo $226, \$ 3^{\circ}, \mathrm{CF} / 88$ ), não significando isto equiparação com o casamento, tanto que o constituinte manifestou, expressamente, o desejo que a lei facilite a sua conversão em matrimônio. Por óbvio não se converte o que já é igual e a Constituição não contém termos ou expressões inúteis, máxima exegética que convém relembrar.

Ademais, não haveria qualquer interesse em se converter a união estável em casamento se àquela fossem conferidos todos os efeitos próprios do matrimônio, devendo o legislador atentar para este fato, sob pena de, ao aproximar em demasia os dois institutos, desestimular a conversão de um em outro, esvaziando o sentido da norma constitucional e incorrendo em velada inconstitucionalidade.

Sobre o desinteresse na conversão, gerado pela exagerada interferência estatal nas uniōes de fato, pertinente a seguinte advertência de Lourival Silva Cavalcanti:

6 DINIZ, Maria Helena. Curso de direito civil brasileiro, v. 5: direito de família. 19. ed. rev., aum. e atual. de acordo com o novo Código Civil (Lei n. 10.406, de 10-1-2002) e o projeto de lei n. 6.960/2002. São Paulo: Saraiva, 2004, p. 371-373. 
Ora, se a lei ordinária, em vez de cuidar do mister que lhe foi determinado pela Constituição, diretamente atribui qualquer parcela do efeito civil à união estável, sem que para tanto se deva proceder à conversão, torna esta desnecessária. E o faz na razão inversa dos efeitos que assim oferece, ou seja, faz tanto menor o interesse na conversão, quanto maior o número de efeitos conjugais que confere à união não convertida. Portanto, qualquer forma de legislação que subtraia aos integrantes da união estável seu eventual interesse pela conversão dela em casamento, ainda que em parte, contraria a Constituição. E isso evidentemente ocorrerá se lhe forem diretamente conferidos os efeitos do matrimônio civil, principalmente os mais relevantes sob o aspecto prático, como a participação no patrimônio, os alimentos e os direitos sucessórios. Se tais questôes encontram disciplina fora do casamento, haver-se-ia de cogitar da conversão para quê??

A disciplina constitucional, ao cogitar da conversão da união estável em casamento, deixou ao legislador ordinário não a sua regulamentação para atribuir-lhe alguns ou todos os efeitos do matrimônio, mas tão somente a disciplina dos problemas que costumam acontecer ao término da união familiar não estruturada nos moldes do casamento civil.

A orientação infraconstitucional não pode anular a liberdade daqueles que não desejam se submeter ao regime típico de casamento, sob pena de tornar ineficaz a parte final do $\$ 3^{\circ}$ do artigo 226 da Carta Magna. Não compete ao legislador regulamentar a própria relação informal, atribuindo-lhe direta e autoritariamente os efeitos da sociedade conjugal.

Não há, portanto, que se falar em isonomia entre casamento e união estável. O princípio da isonomia, diz Celso Antônio Bandeira de Mello, "preceitua que sejam tratadas igualmente as situações iguais e desigualmente as desiguais. Donde não há como desequiparar pessoas e situações quando nelas não se encontram fa-

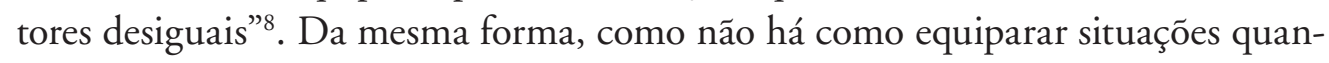
do nelas se encontram claros fatores de desigualação, como é o caso.

Ambos (casamento e união estável) são entidades familiares, porém com características fundamentalmente distintas.

A equiparação total, em direitos e obrigações, da união estável e do casamento, por outro lado, desestimularia a conversão de um em outro, esvaziando o sentido da norma constitucional.

7 CAVALCANTI, Lourival Silva. União estável - a inconstitucionalidade de sua regulamentação. São Paulo: Saraiva, 2003, p. 64-65.

8 BANDEIRA DE MELLO, Celso Antônio. O conteúdo jurídico do princípio da igualdade. 3. ed. São Paulo: Malheiros, 2001, p. 35. 


\section{SITUAÇÕES DE PERPLEXIDADE CAUSADAS POR INTERPRETAÇÕES DIVERGENTES DO TEXTO CONSTITUCIONAL}

Se a moldura normativa das unióes de fato, construída a partir da necessidade de regulamentação infraconstitucional do art. $226, \S 3^{\circ}$, da $\mathrm{CF} / 88$ já atraía críticas, a situação atual suscita perplexidades.

Jurisprudentes se mostram perplexos diante da multiplicidade de interpretações dadas pelos tribunais aos dispositivos legais que versam sobre a matéria. Ora se ampliam, ora se restringem direitos dos companheiros quando comparados aos dos cônjuges. Em outras situações, se estendem aos cônjuges situações antes previstas apenas aos companheiros.

Em situações em que o companheiro se viu em posição mais vantajosa que a do cônjuge, o Superior Tribunal de Justiça optou pela aplicação do estatuto da união estável ao casamento. Nesse sentido foi o julgamento do RESP n. 821.660 DF. Confira-se a ementa:

DIREITO CIVIL. SUCESSÕES. DIREITO REAL DE HABITAÇÃO DO CÔNJUGE SUPÉRSTITE. EVOLUÇÃO LEGISLATIVA. SITUAÇÃO JURÍDICA MAIS VANTAJOSA PARA O COMPANHEIRO QUE PARA O CÔNJUGE. EQUIPARAÇÃO DA UNIĀO ESTÁVEL.

1. O Código Civil de 1916, com a redação que lhe foi dada pelo Estatuto da Mulher Casada, conferia ao cônjuge sobrevivente direito real de habitação sobre o imóvel destinado à residência da família, desde que casado sob o regime da comunhão universal de bens.

2. A Lei n. 9.278/96 conferiu direito equivalente aos companheiros e o Código Civil de 2002 abandonou a postura restritiva do anterior, estendendo o benefício a todos os cônjuges sobreviventes, independentemente do regime de bens do casamento.

3. A Constituição Federal (artigo 226, $\$ 3^{\circ}$ ) ao incumbir o legislador de criar uma moldura normativa isonômica entre a união estável e o casamento, conduz também o intérprete da norma a concluir pela derrogação parcial do $\$ 2^{\circ}$ do artigo 1.611 do Código Civil de 1916, de modo a equiparar a situação do cônjuge e do companheiro no que respeita ao direito real de habitação, em antecipação ao que foi finalmente reconhecido pelo Código Civil de 2002.

4. Recurso Especial improvido.

Os trechos do voto proferido pelo eminente Ministro Sidnei Beneti esclarecem a moldura fática da demanda:

19. Instaurou-se, assim, um certa perplexidade, pois, entre a edição dessa lei e o início da vigência do Código Civil de 2002, uma interpretação literal das normas de regência então vigentes, autorizavam concluir que o companheiro sobrevivente estava em situação mais vantajosa do que o cônjuge sobrevivente (que não fosse casado pelo regime da comunhão universal de bens). 
Perceba-se que o direito real de habitação, até então exclusivo do cônjuge supérstite, havia sido estendido ao companheiro sobrevivente por força do parágrafo único do artigo $7^{\circ}$, da lei 9.278/96, de maneira mais abrangente, conferindo ao companheiro sobrevivente um direito subjetivo que não socorria à maioria dos cônjuges em idêntica situação.

Examinando-se as consequências dessa exegese tem-se o seguinte: Se duas pessoas vivessem em união estável e uma delas falecesse a outra teria a segurança de continuar vivendo no imóvel em que residiam. Se porém, essas mesmas pessoas resolvessem se casar, o que provavelmente ocorreria sob o regime da comunhão parcial, já que esse era o regime legal a partir de 1977, o cônjuge sobrevivente não teria mais assegurado o direito de continuar habitando o imóvel da família.

20. O casamento, a partir do que se extrai inclusive da Constituição Federal, conserva posição juridicamente mais forte que a da união estável. Não se pode, portanto, emprestar às normas destacadas uma interpretação dissonante dessa orientação constitucional.

(...)

21. Considerando, pois, que a interpretação literal das normas postas levaria à conclusão de que o companheiro estaria em situação privilegiada em relação ao cônjuge e, bem assim, que essa exegese, propõem uma situação de todo indesejada no ordenamento jurídico brasileiro, é de se rechaçar a adoção dessa interpretação literal da norma.

22. Uma interpretação que melhor ampara os valores espelhados na Constituição Federal é aquela segundo a qual o artigo $7^{\circ}$ da Lei n. 9.278/96 teria derrogado, a partir da sua entrada em vigor, o $\$ 2^{\circ}$ do artigo 1.611 do Código Civil de 1916, de modo a neutralizar o posicionamento restritivo contido na expressão "casados sob o regime da comunhão universal de bens".

23. Em outras palavras é de se admitir que a Constituição Federal (artigo 226, $\$ 3^{\circ}$ ) ao exortar o legislador a criar de uma moldura normativa pautada pela isonomia entre a união estável e o casamento, exortou também o intérprete da norma e o juiz a concluírem pela derrogação parcial do $\$ 2^{\circ}$ do artigo 1.611 do Código Civil de 1916, de modo a equiparar a situação do cônjuge e do companheiro no que respeita ao direito real de habitação.

24. Perceba-se que, dessa maneira, tanto o companheiro, como o cônjuge, qualquer que seja o regime do casamento, estarão em situação equiparada, adiantando-se, de tal maneira, o quadro normativo que só veio a se concretizar de maneira explícita, com a edição do novo Código Civil.

É preciso analisar se haverá a imposição do art. 1641, inc. $\mathrm{II}^{9}$ aos companheiros.

A questão se dá em virtude da falta de previsão legal expressa para a aplicação desta norma aos companheiros.

9 Art. 1.641. É obrigatório o regime da separação de bens no casamento: II - da pessoa maior de 70 (setenta) anos; 
Álvaro Villaça Azevedo aponta positivamente para tal situação. "Verifique-se, nesse passo, que, se um dos conviventes for sexagenário, deve aplicar-se à relação convivencial o regime obrigatório da separação de bens, tal como ocorre no casamento, para não haver tratamentos desiguais"10 _11. O doutrinador não deixa qualquer dúvida no sentido de que é favorável à equiparação dos efeitos jurídicos dos institutos em comento. Washington de Barros Monteiro posiciona-se favoravelmente à aplicação do art. 1.641, inc. II aos companheiros. ${ }^{12}$

O mesmo Superior Tribunal de Justiça também tem feito a interpretação extensiva inversa, ou seja, atribuindo à união estável restrições expressamente previstas para o casamento (e somente para o casamento) como é o caso da obrigatoriedade de adoção do regime de separação de bens para os nubentes maiores de 70 anos. Confira-se o julgado abaixo:

DIREITO DE FAMÍLIA. UNIĀO ESTÁVEL. COMPANHEIRO SEXAGENÁRIO. SEPARAÇÃO OBRIGATÓRIA DE BENS. ART. 258, \$ ÚNICO, INCISO II, DO CÓDIGO CIVIL DE 1916.1. Por força do art. 258, \$ único, inciso II, do Código Civil de 1916 (equivalente, em parte, ao art. 1.641, inciso II, do Código Civil de 2002), ao casamento de sexagenário, se homem, ou cinquentenária, se mulher, é imposto o regime de separação obrigatória de bens. Por esse motivo, às unióes estáveis é aplicável a mesma regra, impondo-se seja observado o regime de separação obrigatória, sendo o homem maior de sessenta anos ou mulher maior de cinquenta.2. Nesse passo, apenas os bens adquiridos na constância da uniáo estável, e desde que comprovado o esforço comum, devem ser amealhados pela companheira, nos termos da Súmula n. 377 do STF.3. Recurso especial provido (REsp 646.259/RS, Rel. Ministro Luis Felipe Salomão, Quarta Turma, julgado em 22/06/2010, DJe 24/08/2010).

O mesmo tribunal manifestou-se em 2015, mantendo a posição anteriormente exarada, a saber:

[...] 5. Apesar do inciso II do art. 1.641 do CC/02 impor o regime da separação obrigatória de bens somente no casamento da pessoa maior de 60 anos (70 anos após a vigência da Lei n. 12.344/2010), a jurisprudência desta egrégia Corte Superior estendeu essa limitação à união estável quando ao menos um dos companheiros contar tal idade à época do início do relacionamento, o que não é o caso. Precedentes ${ }^{13}$.

10 AZEVEDO, Álvaro Villaça. Estatuto da família de fato: De acordo com o atual Código Civil Lei n. 10.406, de 10-01-2002. São Paulo: Atlas, 2011, p. 415.

11 Apesar de a edição consultada ser de 2011, o autor ainda trabalha com o texto antigo, que foi alterado em 2010 pela Lei n. 12.344, para septuagenários.

12 MONTEIRO, Washington de Barros. Curso de direito civil: direito de família. São Paulo: Saraiva, 2004, p. 48.

13 BRASIL. Superior Tribunal de Justiça. Recurso Especial n. 1.383.624-MG (2013/0146258-6), julgado em 02/06/2015, Relator Min. Moura Ribeiro. No mesmo sentido, BRASIL. Superior 
No entanto, a doutrina critica este posicionamento porque não se pode fazer interpretação extensiva para restringir direitos ${ }^{14}$. Há julgado nesta mesma direção, provando quão conturbado é o tema dentro do cenário jurídico nacional. ${ }^{15}$ É exatamente o que ocorre nesta situação.

O que se está a fazer é estender a aplicação para os companheiros de uma norma que restringe direitos porque não permite que o maior de setenta anos escolha seu regime de bens.

Por outro lado, se esta interpretação não se impuser, as fraudes se consolidarão porque as pessoas com mais de setenta anos se valerão da união estável para não terem de se submeter ao regime de separação obrigatória, quando assim não lhes for interessante. Como se pode observar, este assunto admite a análise sob diversos pontos. Aqui se defende o tratamento desigual para a união estável e para o casamento. "Ainda, se a regra gera restrição para o casamento, não existindo hierarquia entre as categorias familiares, não há razão para sua aplicação à união estável, pois são institutos diferentes tratados de maneiras distintas quanto aos direitos e deveres"16.

Todavia, o casamento não pode ser desestimulado pela legislação, uma vez que a própria Constituição estabelece que a lei deve facilitar a conversão da união estável nele. Há que se fazer um recorte epistemológico para justificar o entendimento de Débora Brandão acerca da aplicação do art. 1.641 do CC, sustentado desde $2004^{17}$. Não se justifica a imposição do regime de separação obrigatória em nenhum dos casos expostos pela legislação. No que concerne ao maior de setenta anos, trata-se de dispositivo flagrantemente inconstitucional porque presume incapaz quem é capaz, violando a dignidade da pessoa humana.

Sendo assim, parece não haver outra saída, neste caso, que a não aplicação da regra de hermenêutica que veda a interpretação extensiva para restringir direitos, enquanto se aguarda a revogação do art. 1.641 do CC.

Ainda relacionado ao regime de bens, é de rigor analisar a aplicação do art. 1.647 do CC aos companheiros, o que se pode denominar de "autorização convivencial".

Tribunal de Justiça. Recurso Especial n. 1403419-MG (2013/0304757-6), julgado em 11/11/2014. Relator Min. Ricardo Villas Bôas Cueva.

14 Neste sentido, TARTUCE, Flávio. Direito civil. Rio de Janeiro: Forense, 2017, p. 375, por exemplo.

15 BRASIL. Tribunal de Justiça do Rio Grande do Sul. Apelação Cível n. 70027870567, julgado em 08/07/2009. Relator Des. Sérgio Fernando Silva de Vasconcellos Chaves.

16 TARTUCE, Flávio. Direito civil. Rio de Janeiro: Forense, 2017, p. 375.

17 BRANDÃO, Débora Vanessa Caús. Regime de bens no novo Código Civil. São Paulo: Saraiva, 2007. 
Exceto no regime de separação, exige-se dos casados a autorização do outro cônjuge para a prática dos atos jurídicos ali elencados.

O Código de Processo Civil (CPC) vigente determina a autorização conjugal para as açóes que versem sobre direito real imobiliário, salvo no regime de separação absoluta, nos moldes do CC. A diferença reside no art. $73, \mathbb{3} 3^{\circ}$ do diploma processual que reconhece a aplicação desta exigência de autorização para os companheiros.

Flávio Tartuce mantém-se refratário à aplicação do art. 1.647 do CC para todos os incisos, mas aponta que há posicionamento no STJ favorável à exigência da autorização no caso de alienação ${ }^{18}$. Entretanto, aquele tribunal surpreendentemente afirma que a autorização convivencial não é de rigor para a prestação de fiança e aval, por exemplo. A justificativa é a de que "[...] é por intermédio do ato jurídico cartorário e solene do casamento que se presume a publicidade do estado civil dos contratantes, de modo que, em sendo eles conviventes em união estável, hão de ser dispensadas as vênias conjugais para a concessão de fiança" ${ }^{19}$.

Por coerência jurídica, entende-se que a autorização convivencial deve ser exigida, se não for esta a interpretação aplicada, por se estar a dar um tratamento mais gravoso ao casamento que à união estável, que nunca foi o objetivo do legislador. O que se estampou no texto constitucional é a facilitação da conversão da união estável em casamento e não haveria interesse na conversão com maiores ônus do que bônus, ainda mais agora com os efeitos sucessórios equiparados como se abordará adiante.

$\mathrm{Na}$ união estável percebemos haver mais bônus do que ônus, em comparação ao casamento, o que é inconstitucional porque não haverá interesse em conversão da união estável em regime jurídico mais gravoso.

Há outro ponto a se considerar. Se é para ser livre, que o seja em tudo; mas se o fundamento é a garantia dos direitos patrimoniais, a autorização é de rigor, apenas por coerência jurídica.

Sustenta-se, desde o início, o tratamento desigual, mas jamais podendo a união estável ser mais benéfica do que o casamento, porque tal tratamento seria inconstitucional por inviabilizar a conversão preconizada na parte final do art. 226,

18 TARTUCE, Flávio. Direito civil. Rio de Janeiro: Forense, 2017, p. 368. Vide BRASIL. Superior Tribunal de Justiça. Recurso Especial n. 755.830/SP, julgado em 07/11/2006. Relatora Min. Eliana Calmon.

19 BRASIL. Superior Tribunal de Justiça. Recurso Especial n. 1.299.894, Relator Min. Luis Felipe Salomão. 
$\$ 3^{\circ} \mathrm{da} C F$. Se os companheiros almejarem efeitos patrimoniais, que prevejam por escritura pública, dotada de publicidade e toda a formalidade.

Há, ainda, a questão da liberdade.

Afirma Álvaro Villaça Azevedo que "[...] a liberdade, em direito, não pode ser totalmente desapegada de regulamentação; há que se condicionar, pois a de um vai até onde a de outro começa" ${ }^{20}$. E complementa:

Realmente, se é lícito que duas pessoas vivam como marido e mulher, sem serem casadas, não há que admitir-se que uma abandone a outra, por exemplo, ficando com bens em seu nome, e que pertençam, por justiça, a ambos. Essa liberdade seria escravizante, a possibilitar uma lesão, um enriquecimento ilícito, o que é incompatível com o pensamento jurídico. O Direito há que intervir nessas situaçôes. Por isso, melhor será que essa intervenção seja anterior, com a regulamentação do assunto pelo Poder Legislativo, do que saneadora, após a lesão causada, com atuação curativa do Poder Judiciário.

A liberdade deve ser exercida com responsabilidade por parte dos conviventes, de modo que somente deverão se estabelecer numa união estável se tiverem clareza de que podem viver em um relacionamento extramatrimonial, caso contrário, deverão buscar o casamento para que sejam completamente por ele tutelados.

O questionamento que se impõe é a respeito da razão de o Direito ter de intervir em todas as relações. Não se pensa ser a intervenção sadia e necessária.

Para a união estável, a liberdade e a informalidade deveriam imperar. E, em caso de abuso ou outra situação antijurídica, os companheiros se socorreriam do Poder Judiciário e de outros meios de solução de conflitos.

Porém, o trecho final do pensamento de Álvaro Villaça Azevedo reflete claramente o que se consolidou no Brasil, o intervencionismo legislativo em sede de união estável. Afirmava o autor que "não se pode, em sã consciência, admitir que o regramento de conduta, na família de fato, seja inIbidor da liberdade, porque, em direito, cuida-se da liberdade jurídica, quem vive no complexo do relacionamento humano, com as limitaçõos necessárias" ${ }^{21}$.

É sempre paradoxal porque o mesmo doutrinador que tanto escreveu, estudou e elaborou anteprojeto de lei acerca da matéria, não poderia prever que a regulamentação chegaria ao nível de se retirar da união estável, que chegou a ser conhecida como união livre, sua principal característica: a liberdade.

20 AZEVEDO, Álvaro Villaça. Estatuto da família de fato: de acordo com o atual Código Civil - Lei n. 10.406, de 10-01-2002. São Paulo: Atlas, 2011, p. 211.

21 Ibidem, p. 212. 
Mas sem sombra de dúvidas, a situação que mais suscita perplexidade é a concernente ao estatuto sucessório da união estável (CC, art. 1.790), solenemente desconsiderado por respeitáveis julgados, que com bastante ênfase defendem a aplicação aos companheiros do mesmo estatuto sucessório dos cônjuges.

Como se não bastassem todas as discussões que emergiram com a elevação do cônjuge ao patamar de partícipe privilegiado da sucessão, busca -se, agora, fazê-lo dividir essa ribalta com o companheiro, e isso com base em um "isonomismo" jamais imaginado pelo constituinte de 1988, mas que ganhou exponencial repercussão após o julgamento dos Recursos Extraordinários de ns. 878.694 e 646.721 pelo Supremo Tribunal Federal, a ponto de respeitáveis autores passarem a sustentar que teriam sido suprimidas as distinções, no plano dos fatos e no plano normativo, entre Uniāo Estável e Casamento.

Afirma-se, nas academias e nos tribunais, que a Suprema Corte brasileira equiparou a UE e o Casamento, senão em todos os seus efeitos jurídicos, mas certamente na plenitude dos direitos sucessórios. Em outras palavras, todas as regras legais atinentes à sucessão do cônjuge aplicar-se-iam à sucessão do companheiro, inclusive a designação legitimária do art. 1.845.

Entretanto a matéria está longe de ser pacificada. Observe-se que mesmo a doutrina que chamamos de "igualitarista" ou "isonomista" admite a subsistência de algumas diferenças normativas entre as duas entidades familiares. Mesmo essa corrente não abraça a tese de uma equiparação total, absoluta e irrestrita entre cônjuge e companheiro, mas uma equiparação seletiva, somente no tocante às chamadas "normas de solidariedade", a exemplo do direito a alimentos, do direito de comunhão de aquestos, de acordo com o regime de bens, e do direito à concorrência sucessória em igualdade de condições com o cônjuge. Por outro lado, nega-se a equiparação no que pertine às ditas "normas de formalidade", tais como as formas de constituição e dissolução da união estável e do casamento, o procedimento para a alteração do regime de bens, necessariamente judicial no casamento (art. 1.639, $\$ 2^{\circ}$, do CC e art. 734 do CPC/2015) e a obrigatoriedade de outorga conjugal para a prática de determinados atos, exclusiva para o casamento e dispensada na $\mathrm{UE}^{22}$.

Ou seja, a declaração de inconstitucionalidade do art. 1.790 do CCB/2002 pelo STF, de per se, não promoveu uma total equiparação entre Casamento e União Estável, subsistindo o tratamento diferenciado em diversos aspectos.

22 Cf. TARTUCE, Flávio STF encerra o julgamento sobre a inconstitucionalidade do art. 1790 do Código Civil. E agora? Disponível em: <http://www.migalhas.com.br/FamiliaeSucessoes/104 ,MI259678,31047-STF+encerra+o+julgamento+sobre+a+inconstitucionalidade+do+art+179 $0+$ do $>$. 
No julgamento no AI no REsp 1.135.354/PB, conduzido pelo Ministro Luis Felipe Salomão, o Superior Tribunal de Justiça, a seu turno, reconheceu a presença desses traços distintivos. Esse entendimento foi recentemente reproduzido pelo STJ no julgamento do REsp 1337420/RS ${ }^{23}$.

Não se nega, portanto, que, mesmo no plano dos efeitos jurídicos, sobrevivem algumas diferenças entre União Estável e Casamento, especialmente aquelas que tem origem ou se apoiam no título fundador e nas formalidades do casamento -, que são inexistentes na união estável.

Outra situação que nos causa perplexidade é aquela propiciada pela posição dos que defendem a criação do "estado civil" do companheiro. Rodrigo da Cunha Pereira e Ana Carolina B. Teixeira sustentam que "o estado civil reflete a posição da pessoa, com a gama de relações jurídicas da qual faz parte, perante a sociedade. Se a finalidade precípua do estado é esta, não há razões para negar a atribuição de um estado familiar para a união estável. Não há dúvidas de que seria aguçar, ainda mais, o paradoxo já existente quanto à positivação da união estável, mas também refletiria a situação jurídica vivida pelos sujeitos da relação" 24 . Acrescentam que ser de todo "conveniente a atribuição de um estado civil à união estável, com a finalidade de conferir maior segurança às relações jurídicas estabelecidas, tendo como sujeitos desta relação pessoas que vivem em união estável. Embora saibamos que tal fato se consubstancia em um paradoxo, ele tem um escopo protetivo e garantidor, de modo a validar o exercício da liberdade dos sujeitos" 25 .

Com todo respeito, a criação de um estado civil para a união estável só confirmaria o paradoxo sobre o qual estamos refletindo, pois estar-se-ia formalizando e solenizando uma relação de fato, buscada por aqueles que, a priori, não desejavam se submeter aos laços oficiais do casamento.

Essas situações que aDJetivamos de perplexas constituem importante fonte geradora de insegurança jurídica. As interpretações díspares e, muitas vezes contra legem, produzem julgamentos desconexos e confusos que não garantem a mínima estabilidade das relações jurídicas.

Quem convive em união estável hoje, no Brasil, não possui informações claras a respeito das consequências do seu relacionamento afetivo. Não sabe com precisão quais

23 REsp 1337420/RS, Rel. Ministro Luis Felipe Salomão, Quarta Turma, julg. em 22/08/2017, DJe 21/09/2017.

24 "A criação de um novo estado civil no direito brasileiro para a união estável". In: Questôes controvertidas no direito de família e sucessóes. Mário Luiz Delgado e Jones Figueiredo Alves (Coord.). São Paulo: Método, 2005, p. 267-268.

25 Idem. 
os seus deveres jurídicos, se terá ou não direito à sucessão em relação aos bens anteriores ao relacionamento, se poderá alienar um bem imóvel sem a autorização do outro.

Enquanto isso grassa a insegurança entre os operadores jurídicos e jurisdicionados, pois ora se mantém o estatuto convivencial hígido, ora se afasta completamente, ora se afasta por partes. Muitos dos partidários da equiparação limitam-se a estender à união estável os mesmos direitos do casamento, omitindo deveres e restrições do âmbito de abrangência da pretendida isonomia.

\section{A EQUIPARAÇÃO DE EFEITOS JURÍDICOS TRANSFORMA A UNIÃO ESTÁVEL EM UM VERDADEIRO CASAMENTO FORÇADO}

Rude-Antoine, em monografia específica sobre o tema citada no início deste artigo, identifica, na atualidade, duas espécies de casamento forçado: a) aquele casamento imposto a uma pessoa jovem, cuja imaturidade a torna incapaz de compreender o significado do engajamento conjugal; b) o casamento extorquido por coação, violência, temor reverencial ou ameaça por parte do futuro cônjuge ou da família ${ }^{26}$.

O Pacto Internacional de Direitos Civis e Políticos da Assembleia Geral das Nações Unidas de 16 de Dezembro de 1966, em seu artigo 23, proclama o princípio da liberdade do casamento, consubstanciado no direito fundamental do homem e da mulher livremente contraírem matrimônio, e dispõe expressamente que "o casamento não pode celebrar-se sem o livre e pleno consentimento dos futuros cônjuges”.

O princípio da liberdade do casamento, diz Rude-Antoine ${ }^{27}$, se manifesta, inicialmente, na fase antecedente à celebração, quando se afasta qualquer força obrigatória ou vinculatória às convençôes pré-nupciais e às promessas de casamento. Nenhum compromisso assumido anteriormente ao casamento poderá ser executado contra a vontade de um dos nubentes. A doutrina denomina de esponsais o compromisso matrimonial contraído por alguém. Na linguagem comum, chama-se noivado. Como categoria jurídica, é uma promessa de contratar. O rompimento dessa promessa jamais pode dar ensejo à execução forçada, não obstante possa constituir fato gerador da obrigação e indenizar ${ }^{28}$.

26 RUDE-ANTOINE, Edwige. Mariage libre mariage forcé? Paris: Presses Universitaires de France - PUF, 2011, p. 28.

27 Op. cit., p. 69 e segs.

28 A quebra da promessa de casamento por decisão unilateral de um dos compromissados, quando o outro realizou preparativos para o ato, com investimento financeiro, gera obrigação de indenizar os danos materiais, com base nos princípios gerais da responsabilidade civil subjetiva, traduzida na regra geral do art. 186. 
A segunda manifestação do princípio ocorre no momento da celebração e se exterioriza pelo consentimento livre e informado dos nubentes. E finalmente o princípio da liberdade do casamento é confirmado pela faculdade de dissolver o elo matrimonial pelo divórcio.

Estabelecidos os contornos do casamento forçado, como sendo aquele em que violado o princípio da liberdade do casamento, poderíamos afirmar que o tratamento dado à união estável pela ordem jurídica brasileira, especialmente na leitura feita por muitos tribunais e por importantes doutrinadores, implica transformar a união de fato em um casamento forçado.

À medida em que se regulamenta um relacionamento que foi constituído para ser uma união livre e sem nenhuma oficialidade, não se estaria alterando a sua natureza jurídica, para transformá-lo em outro tipo de relacionamento que não foi querido pelas partes?

Já dissemos que o direito de viver informalmente não significa viver à margem da lei. Por isso, a lei reconhece alguns efeitos jurídicos à união estável. Porém uma postura intervencionista do Estado brasileiro carece de legitimidade, como bem adverte Maria Berenice Dias:

A exaustiva regulamentação da união estável a faz objeto de um dirigismo estatal não querido pelos conviventes. Tratando-se de relações de caráter privado, cabe questionar a legitimidade de sua publicização. Assim, passou o Estado a regular não só os vínculos que buscam o respaldo legal para se constituírem, mas também os relacionamentos que escolhem seus próprios caminhos e que não desejam qualquer interferência. ${ }^{29}$

\section{CONCLUSÕES}

Desde a secularização do matrimônio, quando o Estado passou a titularizar o monopólio do antigo sacramento canônico, que se nota uma dificuldade desse mesmo Estado abrir em mão de chancelar as uniões civis e, com isso, dizer quais delas estariam sob a sua tutela. Entender as uniōes de fato como elas realmente são, essencialmente uniōes livres, significa abrir mão dessa potestade. E o Estado tem notória dificuldade em renunciar a qualquer parcela de poder. Veja-se o caso das diversas tentativas legislativas de se ampliar as soluções extrajudiciais privadas, sempre esbarrando no Estado e no seu monopólio da Justiça.

29 DIAS, Maria Berenice. A estatização das relaçôes afetivas e a imposição de direitos e deveres. In: PEREIRA, Rodrigo da Cunha (Coord.). Familia e cidadania: o novo CCB e a vacatio legis. Belo Horizonte: IBDFAM, Del Rey, 2002, p. 307. 
O casamento é o elo social que une o cidadão à pátria e a pátria ao cidadão, diziam os revolucionários de 1789. Por isso a formação desse elo tem que ser chancelado pelo Estado. Exige-se, assim, que a celebração do casamento só possa ser feita por autoridade pública, investida de poder estatal.

Com o surgimento das uniōes de fato, multiplicadas como reflexo da liberdade de escolha que cresceu a partir da secularização, passou o Estado a preocupar-se, em um primeiro momento, em manter o casamento como a forma única de constituição de família (constituir família dependia, portanto, da aquiescência do Estado), surgindo, em consequência, as diversas normas punitivas das uniōes fáticas, abundantes no CC/1916.

Em um segundo momento, mais liberalizante, especialmente sob os influxos do neo-constitucionalismo dos anos 90, Leviatã se deu conta de que não adiantava proibir, perseguir, criminalizar, pois a realidade dos fatos se sobrepunha à realidade normativa. Prolbido o concubinato, doutrina e jurisprudência passaram a distinguir concubinato puro e impuro, de modo a que as restrições legais somente atingissem o concubinato dito impuro. No lugar de proibir ou sancionar, o Estado adota outra estratégia: "regulamentar" extensivamente, atribuindo direitos e deveres, e estabelecendo requisitos e formalidades para as outrora "uniōes livres".

As uniōes de fato passam a gozar de tabula legislativa similar à do casamento, com exceção dos procedimentos de habilitação e formalidades da celebração. A união de fato, que era livre, passa para a tutela estatal, pagando o preço de sua regulamentação. Nada é mais livre. A união de fato também vai demandar agora o reconhecimento do Estado.

Como agravante dessa situação, de invasão do Poder Público nas esferas privadas mais íntimas das pessoas, doutrina e jurisprudência estendem às uniōes de fato todos os demais direitos e deveres do casamento que não tenham sido expressamente mencionados. Quem não se casou para fugir dos efeitos do casamento, agora se submeterá aos mesmos limites e restrições, inclusive no que tange aos impedimentos matrimoniais e aos direitos sucessórios, para, com isso, gozar dos mesmos benefícios.

$\mathrm{Na}$ sociedade atual existe uma tendência de se recusar qualquer tipo de interferência externa nas uniões conjugais, já que o princípio maior deve ser o da liberdade dos cônjuges. Daí a liberdade de casar, de não casar e de dissolver o casamento.

Claro que a própria noção filosófica de liberdade pressupõe a sua limitação. E nesse sentido a liberdade de se casar está limitada por diversos fatores previstos em lei, como a idade dos nubentes, os laços de parentesco, a preexistência de outro vínculo conjugal etc. Tais restrições, por óbvio, não comprometem a liberdade do 
casamento. $\mathrm{O}$ importante é que quaisquer restrições a um direito fundamental de liberdade estejam expressamente previstas em lei.

O que nos parece absurdo, e certamente violador desse direito fundamental de liberdade, é se estender para as uniōes de fato restriçōes antes previstas apenas para o casamento. Fazer isso equivale a forçar o casamento de quem não quis se casar. Obrigar um par convivencial a se submeter a todo o quadro normativo dos pares casamentários implica violar o seu direito fundamental de liberdade.

A união estável precisa retornar à sua origem de união livre. Deve ser protegida pelo Estado, mas seu corolário é a liberdade e a informalidade. Os direitos patrimoniais devem estar à disposição dos companheiros, não automaticamente impostos pela lei.

Não pode haver dois institutos para amparar exatamente os mesmos direitos, assim como não se pode converter união estável em casamento se os dois produzem, exatamente, os mesmos efeitos. O que existe é, tão somente, a mudança do nome e o reconhecimento do estado civil de casado, portanto.

O legislador pode criar regimes jurídicos diferentes para institutos diferentes e isto é perfeitamente constitucional.

Num mundo que luta pela diversidade, as relações não podem ser reducionistas a um modelo apenas. Se os institutos são diferentes, os efeitos jurídicos também deveriam ser. Esta é a premissa.

Os companheiros, quando escolhem a união estável, optam por um regime jurídico diferente do casamento.

Não faz qualquer sentido ter no ordenamento jurídico brasileiro dois institutos tutelando, exatamente, os mesmos bens jurídicos, e com os mesmos efeitos.

Mais uma vez, com toda a vênia, sustenta-se que é equivocado o posicionamento da doutrina e jurisprudência majoritárias, porque retiram das pessoas o seu precioso direito de decidirem como desejam se relacionar do ponto de vista sentimental, não dando qualquer opção para que possam escolher se desejam um relacionamento com efeitos jurídicos consagrados pela legislação ou um relacionamento mais livre, protegido, mas amparado pela liberdade. Invade-se a autonomia da pessoa.

Esse é o paradoxo da união estável: uma união querida livre pela vontade das partes, transformada em um "casamento de fato" pela vontade exclusiva do Estado, pouco importando a vontade dos nubentes.

E nesse particular concluímos que a união estável no Brasil pouco a pouco se converte em um "casamento forçado". 
•• Direito Civil: Estudos | Coletânea do XV Encontro dos Grupos de Pesquisa - IBDCivil

\section{REFERÊENCIAS}

AZEVEDO, Álvaro Villaça. Estatuto da família de fato: de acordo com o novo Código Civil. 2. ed. São Paulo: Atlas, 2002.

BANDEIRA DE MELLO, Celso Antônio. O conteúdo jurídico do princípio da igualdade. 3. ed. São Paulo: Malheiros, 2001.

BRANDÃO, Débora Vanessa Caús. Regime de bens no novo Código Civil. São Paulo: Saraiva, 2007.

CAVALCANTI, Lourival Silva. União estável - a inconstitucionalidade de sua regulamentação. São Paulo: Saraiva, 2003.

DIAS, Maria Berenice. A estatização das relações afetivas e a imposição de direitos e deveres. In: PEREIRA, Rodrigo da Cunha (Coord.). Família e cidadania: o novo CCB e a vacatio legis. Belo Horizonte: IBDFAM, Del Rey, 2002.

DINIZ, Maria Helena. Curso de direito civil brasileiro. 19. ed. rev., aum. e atual. de acordo com o novo Código Civil (Lei n. 10.406, de 10-1-2002) e o projeto de Lei n. 6.960/2002. São Paulo: Saraiva, 2004. v. 5: Direito de família.

MONTEIRO, Washington de Barros. Curso de direito civil: direito de família. São Paulo: Saraiva, 2004.

PEREIRA, Rodrigo da Cunha; TEIXEIRA, Ana Carolina B. Questôes controvertidas no direito de família e sucessões. Coord. Mário Luiz Delgado e Jones Figueiredo Alves. São Paulo: Método, 2005. Série grandes temas de direito privado, v. 3.

PITÃO, José Antônio de França. Uniōes de facto e economia comum. 3. ed. Coimbra: Almedina, 2011.

RUDE-ANTOINE, Edwige. Mariage libre mariage forcé? Paris: Presses Universitaires de France - PUF, 2011.

TARTUCE, Flávio STF encerra o julgamento sobre a inconstitucionalidade do art. 1790 do Código Civil. E agora? Disponível em: <http://www.migalhas.com.br/FamiliaeSucessoes/104,MI259678,31047-STF+encerra+o+julgamento+sobre+a+inconstitucionalidade+do+art+1790+do $>$.

TARTUCE, Flávio. Direito civil. Rio de Janeiro: Forense, 2017. 